\title{
A relict species restricted to a quartzitic mountain in tropical America: an example of microrefugium?
}

\author{
Newton Pimentel de Ulhôa Barbosa ${ }^{1,2 *}$, G. Wilson Fernandes ${ }^{1}$ and Arturo Sanchez-Azofeifa ${ }^{2}$
}

Received: August 29, 2014. Accepted: March 11, 2015

\begin{abstract}
We examined the distribution of Coccoloba cereifera, a tropical endemic species that occurs in a small area in the Espinhaço mountain range, southeastern Brazil. It is hypothesized that its narrow distribution is strongly related to the spatially scattered distribution of sandfields. However, this soil type extends far beyond the small region where $C$. cereifera is currently found, indicating that other factors might be involved in the distribution of this species. Coccoloba cereifera also displays all traits of a relict population in a microrefugium. As a result, we were encouraged to explore other factors potentially related to the distribution of the species. In an attempt to aid in the understanding of the processes and mechanisms that lead C. cereifera to present the narrow actual distribution, we applied two distribution modelling approaches to investigate the potential distribution of the species beyond the small known distribution area. The distribution seems to be strongly associated with sandy patches/grasslands formed among rocky outcrops and is limited by some topoclimatic and/or topographic features. Some of them related to the existence of a microrefugium, a fact also suggested by the pattern of distribution of the species in the past. From the management point of view, the existence of a microrefugium in this area calls for changes in conservation efforts and priorities.
\end{abstract}

Keywords: Coccoloba cereifera, Espinhaço Mountains, maximum entropy, rupestrian grasslands, Serra do Cipó

\section{Introduction}

All over the world, mountain regions present a wide range of environments otherwise only seen over broad latitudinal distances (Spehn et al. 2010). Overall, plants occurring at high elevation have evolved from ancient plants found in lowland habitats, with subsequent enrichment through dispersal along these mountain environments (Arroyo et al. 2010). Furthermore, habitat isolation due to climatic and/or geological events is also responsible for a great $\beta$-diversity, mainly in the tropics (e.g., Janzen 1967; Tang 2012). The tropical Andes, for example, contain approximately one sixth of all known plant species in less than $1 \%$ of the world's terrestrial area (Mittermeier et al. 1997; Richter 2009). In Brazil, despite its world-renowned forests, some mountain regions also present high levels of species richness and endemism (e.g., Safford 1999; Martinelli 2007).

In southeastern Brazil, the vegetation of the Espinhaço mountains is mostly represented by a unique flora known as rupestrian grasslands ('Campos Rupestres') (Fernandes et al. 2014). This vegetation comprises one of the most speciose and highly endemic flora of the tropics, where some families may reach up to $80-90 \%$ endemism (Giulietti et al.
1987). In a broad scale, many factors would be responsible for this high biological diversity, such as the great latitudinal variation (Alves et al. 2014), the presence of a mosaic of phytophysiognomies (Rapini et al. 2008), the ancient age of these geological formations, and the great variety of microclimates (Barbosa 2012). In 2005, the southern portion of this mountain range (in the state of Minas Gerais) was recognized as a Biosphere Reserve by UNESCO. This region has strong climatic differences from the north portion, with higher humidity, lower average temperature and higher average elevations (e.g., Alves \& Kolbek 2010). In addition, according to Echternacht et al. (2011), geological, climatic and biotic conditions are also very different between the northern, central and southern areas of this southern portion, which have many recognized areas of endemism. The largest continuous area of the southern Espinhaço mountain range comprises an endemism unit formed by the regions of Diamantina Plateau and Serra do Cipó. Inside these regions, many small areas present idiosyncratic microclimates, which host several micro-endemic plant species, in general due to the high geological heterogeneity and insularity. One of those species is the trioecious and highly sclerophyllous Coccoloba cereifera (Polygonaceae), which is currently only found in

\footnotetext{
${ }^{1}$ Departamento de Biologia Geral, Instituto de Ciências Biológicas, Universidade Federal de Minas Gerais, PO Box 486, 30161-970, Belo Horizonte, MG, Brazil, Phone number: +55 3134092580

${ }^{2}$ Department of Earth and Atmospheric Sciences, University of Alberta, Edmonton, Alberta, Canada T6G 2E3

*Corresponding Author: newtonulhoa@gmail.com
} 
the region of Serra do Cipó (Ribeiro \& Fernandes 1999; 2000; Silva et al. 2008). As far as we know, this species occurs in a small area of approximately $26 \mathrm{~km}^{2}$ (Ribeiro \& Fernandes 1999; Moreira et al. 2008; 2010). Ribeiro \& Fernandes (2000) postulated that its restricted distribution was strongly related to the clonal growth and spatially scattered distribution of sandfields, a soil type for which the species appeared to show high frequency. However, sandfields extend far beyond this small region, a simple indication that other factors might be involved in the distribution of $C$. cereifera, which displays all traits of a relict population in a microrefugium (see Rull 2009; Mosblech et al. 2011; Hampe \& Jump 2011; Keppel et al. 2011): it is restricted to a small area, shows low genetic diversity, has clonal growth, low dispersal and is also isolated (see Ribeiro \& Fernandes 1999; Moreira et al. 2008; 2010).

The term 'microrefugia' was framed by Rull et al. (1988) in an attempt to explain the persistence in time of high-mountain species on the Venezuelan tepuis (table-top mountain ecosystems occurring in northern South America; also formed by quartzitic or arenitic sandfields). It is thought that during the Pleistocene dry phases in South America (e.g., Vuilleumier 1971), small favourable sites (which idiosyncratic microclimates) might have favoured the persistence of some species in mountain ecosystems, which are well suited to hold microrefugia (McLachlan et al. 2005; González-Astorga et al. 2005; Holderegger \& Thiel-Egenter 2009; Previšić et al. 2009). With the arrival of more humid climates at the end of Pleistocene, many of these species were still present and could readily recolonize the adjacent areas (Rull 2009). However, Pleistocene glacial and interglacial periods may affect mountain species in different ways (Hewitt 2000). In some cases, rapid warming periods are suggested to have promptly reduced distribution ranges and depleted genetic diversity of organisms, thus being confined to microrefugia (Martínez-Freiría 2014). The complex topography of mountain environments creates a range of different microclimates (Geiger 1965) that are of critical importance for species distribution and diversity (Fernandes \& Price 1991; Brown 1994) as well as for the existence of these refuges (Scherrer \& Körner 2010; Dobrowsky 2011).

Microclimates are directly influenced by topographic factors such as elevation, slope or aspect, which have been widely used as predictor variables in distribution models. To generate environmental suitability maps, distribution models make use of environmental data associated with known distributions of the target species. These models have become increasingly important and have been used in many ecological applications (Araújo \& Peterson 2012); e.g., to understand species' ecological requirements (Raxworthy et al. 2003; Elith et al. 2006), to understand species biogeography (Pearson 2006); as well as to identify historical refugia for biodiversity (Waltari et al. 2007; Carnaval \& Moritz 2008; Vega et al. 2010).

In an attempt to improve in the understanding of the processes and mechanisms that lead C. cereifera to show the actual narrow distribution we apply two distribution modelling approaches. First, we constructed a model to investigate the potential distribution of the species beyond the small known distribution area, and a second model to examine its distribution in the past; with the goal of finding a pattern for a microrefugium formation. Finally, we discuss some implications of the findings for the construction of distribution models for narrow endemic species in the speciose rupestrian grassland vegetation.

\section{Material and methods}

\section{The species native range}

The distribution range of Coccoloba cereifera Schw. is only located in Serra do Cipó, a region in the southern portion of the Espinhaço mountain range (Fig. 1). The Espinhaço Mountains are of quartzitic origin, running north-south $\left(10^{\circ}-20^{\circ} \mathrm{S}\right)$ ca. $1200 \mathrm{~km}$ with two distinct parts: Chapada Diamantina in the north and Serra do Espinhaço itself in the south (Rizzini 1979). The region of Serra do Cipó ranges 650-1670 $\mathrm{m}$ a.s.l. in altitude and is predominantly covered by grasslands, with few shrubs and small trees except near watercourses where small riparian forests are found (Giulietti et al. 1987). Above $900 \mathrm{~m}$ soils are shallow, acidic, and nutrient-poor, with excessively drained sands that are highly erodable (Marques et al. 2002; Medina \& Fernandes 2007; Negreiros et al. 2012). Quartzitic outcrops are common and in their crevices a more humid soil can be found. The regions above $900 \mathrm{~m}$ in Serra do Cipó and across most of the Espinhaço mountain range support highly xerophytic vegetation with high plant species diversity (Rizzini 1979; Giulietti et al. 1987), with many congeneric sympatric species (e.g., Madeira \& Fernandes 1999; Lüttge et al. 2007). Substantial overlapping of distribution is present, characterizing this region as an endemism area (Müller 1973; Morrone 1994; 2001; Echternacht et al. 2011). Its climate is characterized by dry winters and rainy summers with an annual mean rainfall of $1500 \mathrm{~mm}$ and an annual mean temperature of 17.4 to $19.8^{\circ} \mathrm{C}$ (Madeira \& Fernandes 1999).

\section{Modelling approaches}

To understand which variables are involved in the potential distribution of the species beyond the small known distribution area we carried out a distribution model for C. cereifera for its native distribution area and surroundings, with a fine resolution of $\sim 0.000278^{\circ}(\sim 30 \mathrm{~m})$ (Model A). To explore the distribution of this species in the past, we surveyed a model for $C$. cereifera for its native distribution area, with a coarse resolution of $\sim 0.0082^{\circ}(\sim 1 \mathrm{~km})$, and projected this model to three scenarios: $\sim 120.000$ years B.P. (last interglacial maximum), $\sim 21.000$ years B.P. (last glacial maximum), and $\sim 6000$ years B.P. (Mid-Holocene) (Model B). 


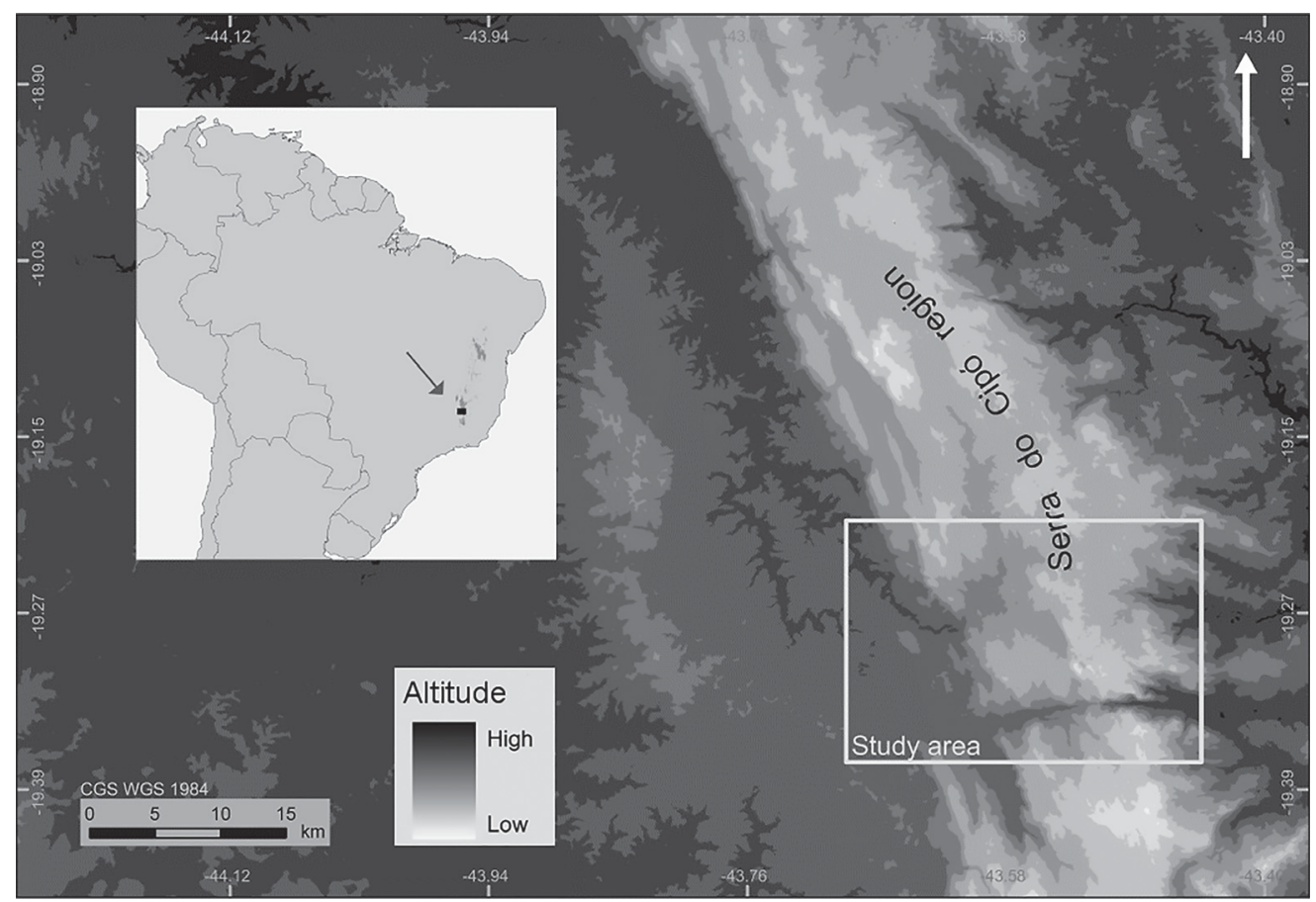

Figure 1. Location of the study area within the Espinhaço range in Brazil.

\section{Occurrence points used in both models}

To construct both distribution models we acquired all known occurrence points from the native distributions of C. cereifera. More than two hundred points were obtained for the occurrence of the species; they were within the small known area of approximately $26 \mathrm{~km}^{2}$ where the species was argued to be solely distributed (Ribeiro \& Fernandes 1999). Many points were ruled out due to overcrowding in the same pixel; hence reducing the effects of spatial autocorrelation (see Hernandez et al. 2006; Phillips et al. 2006; Pearson et al. 2007; Thorn et al. 2009). Hence, 162 points of occurrence for the species were used for model A (with a fine resolution), and 28 points were used for the model B (with a coarse resolution).

\section{Model A}

Our dataset for model A (all variables were clipped to the study area as shown in Figure 1) was composed of an ASTER GDEM (Global Digital Elevation Model, property of METI and NASA) obtained at the Earth Remote Sensing Data Analysis Center (ERSDAC, http://www.gdem.aster. ersdac.or.jp) with a spatial resolution of $\sim 0.000278^{\circ}(\sim 30$ $\mathrm{m})$ and its derivations: slope and aspect, created with the Surface Analysis toolbox in ArcView (ESRI, Redlands, CA), and a wetness index created with the raster calculator in ArcView $^{\odot}$ (ESRI, Redlands, CA), following Beven \& Kirkby (1978); as shown in Equation 1.

WETNESS INDEX $=$ LN $($ AS/TANB $)($ EQUATION 1$)$
Additionally, we used a solar radiation layer for the winter (in the southern hemisphere some south-face regions receive less radiation in the winter) (resolution of $\sim 0.000278^{\circ}$ ) created with the Solar Analyst toolbox in ArcView ${ }^{\circ}$ (ESRI, Redlands, CA), percent bare cover (Hansen et al. 2003) acquired from the Global Land Cover Facility of University of Maryland (http://glcf.umiacs.umd.edu/ data/vcf), originally with a spatial resolution of $\sim 0.0045^{\circ}$ $(\sim 500 \mathrm{~m})$, resampled to $\sim 0.000278^{\circ}(\sim 30 \mathrm{~m})$ for analysis, NDVI (normalized difference vegetation index) layers for the dry season and wet season, and the annual NDVI range, all provided by the Geochronos database (MODIS 16-Day L3 Global 250m SIN Grid, http://www.geochronos.org), originally with a spatial resolution of $\sim 0.00225^{\circ}(\sim 250$ $\mathrm{m})$, resampled to $\sim 0.000278^{\circ}(\sim 30 \mathrm{~m})$ for analysis, and a potential cold air pooling algorithm (CAP), created following Lundquist et al. (2008).

We performed a test for multicolinearity examining correlation among all variables (Pearson correlation test, $\mathrm{r}>$ 0.85) (e.g., Kumar \& Stohlgren 2009) based on 1000 random points for the calibration area; the variables did not shown high correlation structure in the study area.

We used the maximum entropy approach for model development, which has been found to have the best performance among many modelling methods (Elith et al. 2006; 2011; Hernandez et al. 2006). MaxEnt software version 3.3.3 (Computer Sciences Department - Princeton University, 2004) was utilized to generate a statistically significant logistic model of potential occurrence (environmental suitability) for C. cereifera. As MaxEnt generates a probability 
distribution output between 0 and $100 \%$, we selected the lowest presence decision threshold (LPT), which enables the validation and interpretation of the model (Liu et al. 2005; Pearson et al. 2007). The LPT is a binary approach which defines the smallest possible range of suitable habitat that also includes all the presence data points used in model (Pearson et al. 2007). The model was validated by the area under the receiver operating characteristic curve (AUC), which is considered an effective indicator of model performance, independent of the threshold probability (Manel et al. 2001). Additionally, we conducted excursions to the predicted areas (using the LPT binary output map) as an attempt to observe the presence or absence of the species in these areas. These data together with some occurrences from the literature (Ribeiro \& Fernandes 1999) and herbaria (Missouri Botanical Garden and Herbarium of The New York Botanical Garden, accessed through GBIF Data Portal, data.gbif.org, 2010-09-15, *two occurrence points are out-to-date, from 70') were used to construct a confusion matrix describing at which frequency the presences and absences are predicted correctly or incorrectly (Fielding \& Bell 1997). To understand the importance of each variable, we also selected the jackknife approach in MaxEnt.

\section{Model B}

Bioclimatic variables are good predictors of the impacts of climate change on biodiversity (Pearson \& Dawson 2003; Werneck et al. 2010). It is expected that these variables may satisfactorily determine the distribution of $C$. cereifera in a historical context, given that they represent strong climate associations with biotic environment (Schrag et al. 2008).

The bioclimatic variables for the present day (19502001) and for the last interglacial maximum ( 120.000 years B.P.; Otto-Bliesner et al. 2008) were downloaded from the project Worldclim at a spatial resolution of $0.0083^{\circ}(\sim 1 \mathrm{~km})$ (Hijmans et al. 2005). The climate data used for the last glacial maximum and middle Holocene follow the general circulation model ECHAM3 (DKRZ, 1992), available on the webpage of the Intercomparison Project paleoclimate modeling (PMIP, http://pmip.lsce.ipsl.fr) and was kindly provided by Werneck, F. The heterogeneity of paleoclimate in South America makes the most general circulation models simulate past climates with a very low definition (Werneck et al. 2010). Although models based on regional patterns probably have a higher performance in simulating the paleoclimate, regional climate reconstructions are not yet available for the South American continent. Thus, the ECHAM3 general circulation model was chosen for this study because it has, among all models used for this purpose, the best resolution and performance (e.g., Werneck et al. 2010). The variable elevation, used in conjunction with all other variable groups, was downloaded from the Worldclim project in a spatial resolution of $0.0083^{\circ}(\sim 1 \mathrm{~km})$ (Hijmans et al. 2005).
All bioclimatic variables were cut to cover the Brazilian territory, encompassing all known distribution of rupestrian grasslands. We performed a Pearson's correlation test to avoid the presence of multicollinearity among the variables. Those highly correlated $(r>0.85)$ were kept in the model in a qualitative way, based only on their biological relevance. Following this protocol, from 19 bioclimatic variables initially selected, only nine were retained in the final model (in conjunction with the variable "elevation").

The construction of the distribution model was also performed by the maximum entropy approach (MaxEnt), which was used for the generation of a statistically significant logistic model for the actual distribution of C. cereifera, that has been projected to past scenarios. We also used the lowest presence decision threshold (LPT) to construct binary maps.

\section{Results}

\section{Model A}

The model A successfully predicted the potential distribution of $C$. cereifera with good performance, as evidenced by the AUC of 0.96 (Figs. 2-3). Generally, values $>0.9$ are considered an indicative of high accuracy models (Swets 1988). Field surveys were then undertaken and aided in the identification of new occurrence points, indicating that the distribution area for C. cereifera was larger than the area previously known. The species currently has a distribution area of approximately $35 \mathrm{~km}^{2}$. For a LPT threshold the success rate (accuracy) derived from the confusion matrix was ca. $74 \%$ and the sensibility, which is the probability of a true occurrence pixel be classified correctly, as ca. $92 \%$.

According to the jackknife test of variable importance, the variable with highest gain when used in isolation was the dry season NDVI, which therefore appears to have the most useful information by itself. For example, the model predicts that the environmental suitability for $C$. cereifera decreases with an increase in the dry season NDVI, indicating a tendentious distribution of the species across areas that present dry/low productivity in the dry season. The environmental variable that most decreased the gain when omitted was altitude, which therefore appears to have the most information that is not present in the other variables. Altitude is an important variable probably because many other factors are related to it, e.g., temperature, humidity, and pressure (Fernandes \& Price 1991 and references there in).

The jackknife procedure demonstrates the most important variables as leaving it out does not decrease model fit or test statistics. On the other hand, the "percent contribution" (calculated as the model is being generated) estimated which variables were mostly used, or rather, which ones most contributed to the gain of the model. The variable with the greatest relative contribution to the model was dry season NDVI (26.8\%), followed by percent bare soil (18.9\%), 


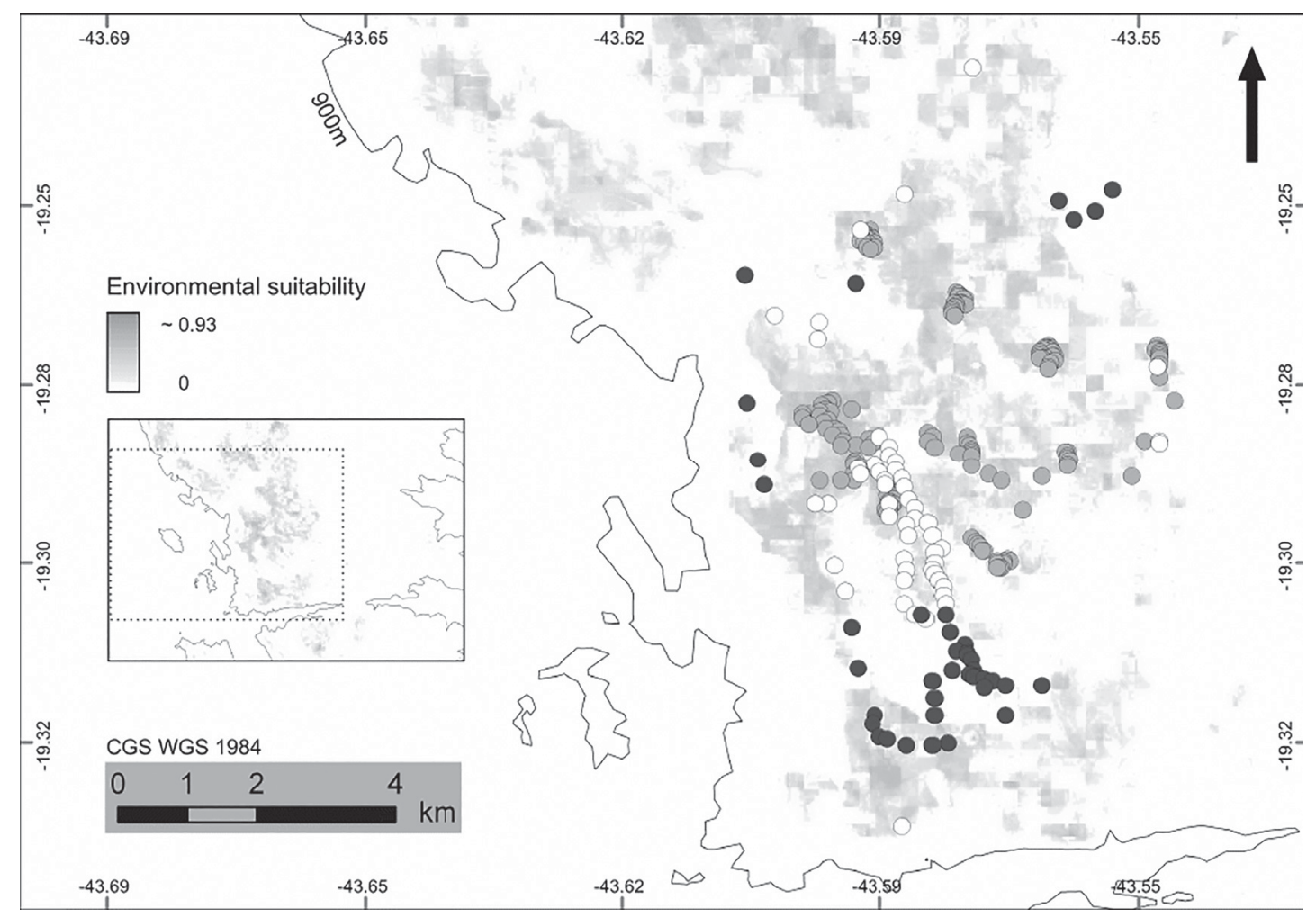

Figure 2. Environmental suitability for Coccoloba cereifera Schw. (Polygonaceae) within the study area. Gray circles are the occurrence points for the species used to construct the model; white circles are the new occurrence points; and black circles are absences.

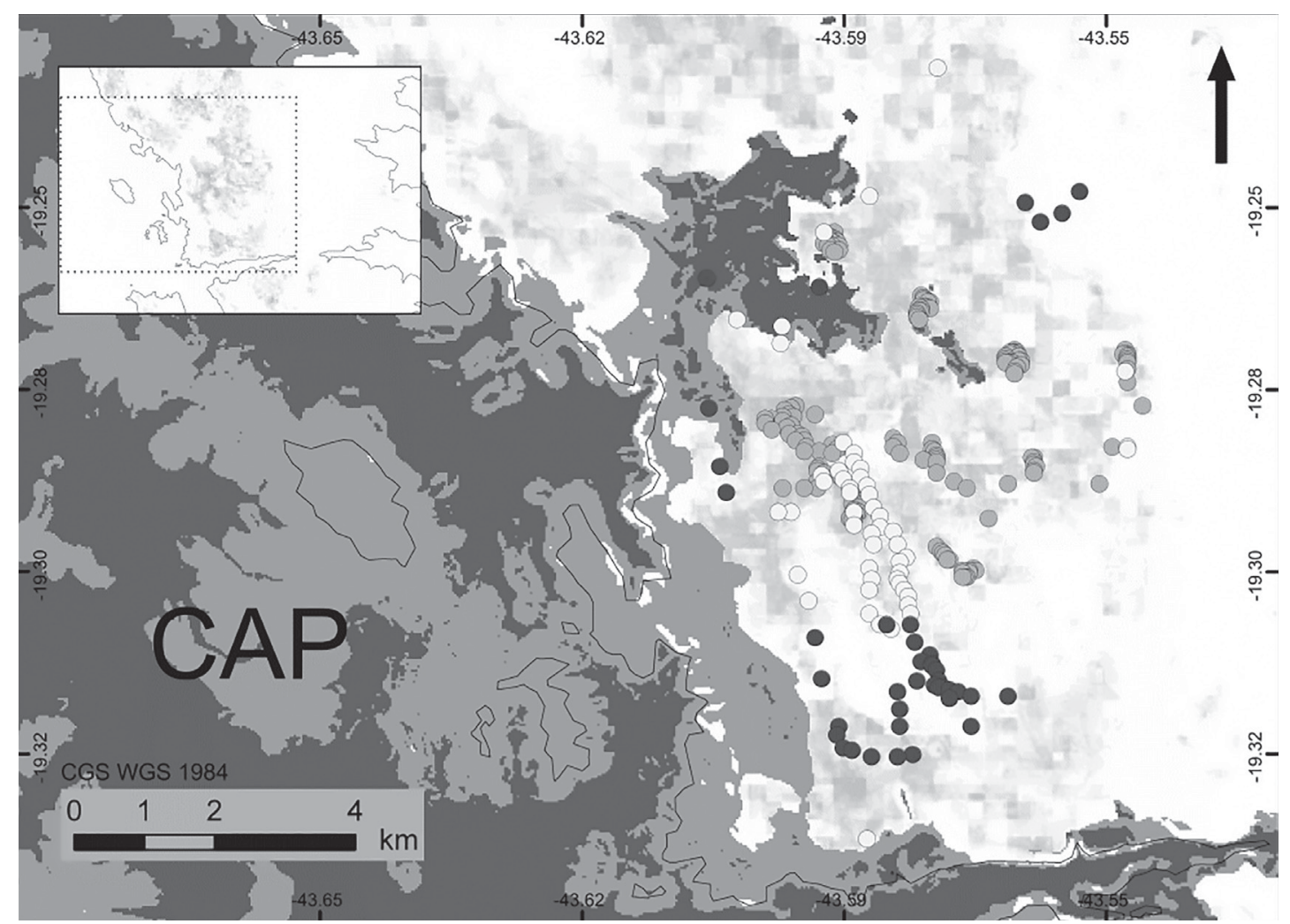

Figure 3. Potential cold air pooling (CAP) areas surrounding areas with high environmental suitability for Coccoloba cereifera Schw. (Polygonaceae) within the study area. 
altitude (18.7\%), CAP (12.7\%), NDVI range (11.6\%), wet season NDVI (4.4\%), aspect (3.7\%), and slope (2.9\%). Wet index and winter solar radiation contributed with less than $1 \%$ each.

\section{Model B}

The model B also showed a satisfactory performance, as illustrated in the AUC of 0.99 (Fig. 4). The variable presenting the highest gain when used alone was altitude, i.e., the variable that shows the most useful information by itself. The variable inducing the lowest gain when omitted was the precipitation of wettest quarter, which seems to have much information not present in other variables.

The variable with the largest relative contribution to the model was altitude (38.3\%), followed by precipitation of wettest quarter (33.2\%), temperature seasonality $(17.5 \%)$, precipitation of driest quarter $(7.7 \%)$, mean temperature of coldest quarter $(1.6 \%)$, and isothermality (1.2\%). The variables precipitation of driest month, precipitation seasonality, temperature annual range and mean temperature of warmest quarter contributed less than $1 \%$ each.

The distribution area predicted to the last interglacial maximum seems very unrealistic, with some sparse regions which have been predicted far from the core distribution area achieved from the last glacial maximum to current days (Fig. 4A). However, this absence of environmental suitability for the species in central Brazil would be an evidence of strong climatic oscillations similar to those that were responsible to shape the actual distribution of C. cereifera in the Holocene (e.g., Miller et al. 2013). Our results showed a predicted suitability area of ca. $645,000 \mathrm{~km}^{2}$ for C. cereifera in the last glacial maximum ( 21.000 years B.P.) (Fig. $4 \mathrm{~B})$, followed by a substantial reduction of ca. $86 \%$ of this area in the years centered in the middle Holocene ( 6.000 years B.P.) (Fig. 4C). Moreover, the current environmental suitability area predicted for the species is more than $99 \%$ smaller than the distribution in the last glacial maximum, comprising ca. $3,172 \mathrm{~km}^{2}$ (Fig. 4D). These values were calculated through the LPT threshold with an equal area projection (Albers Conic).
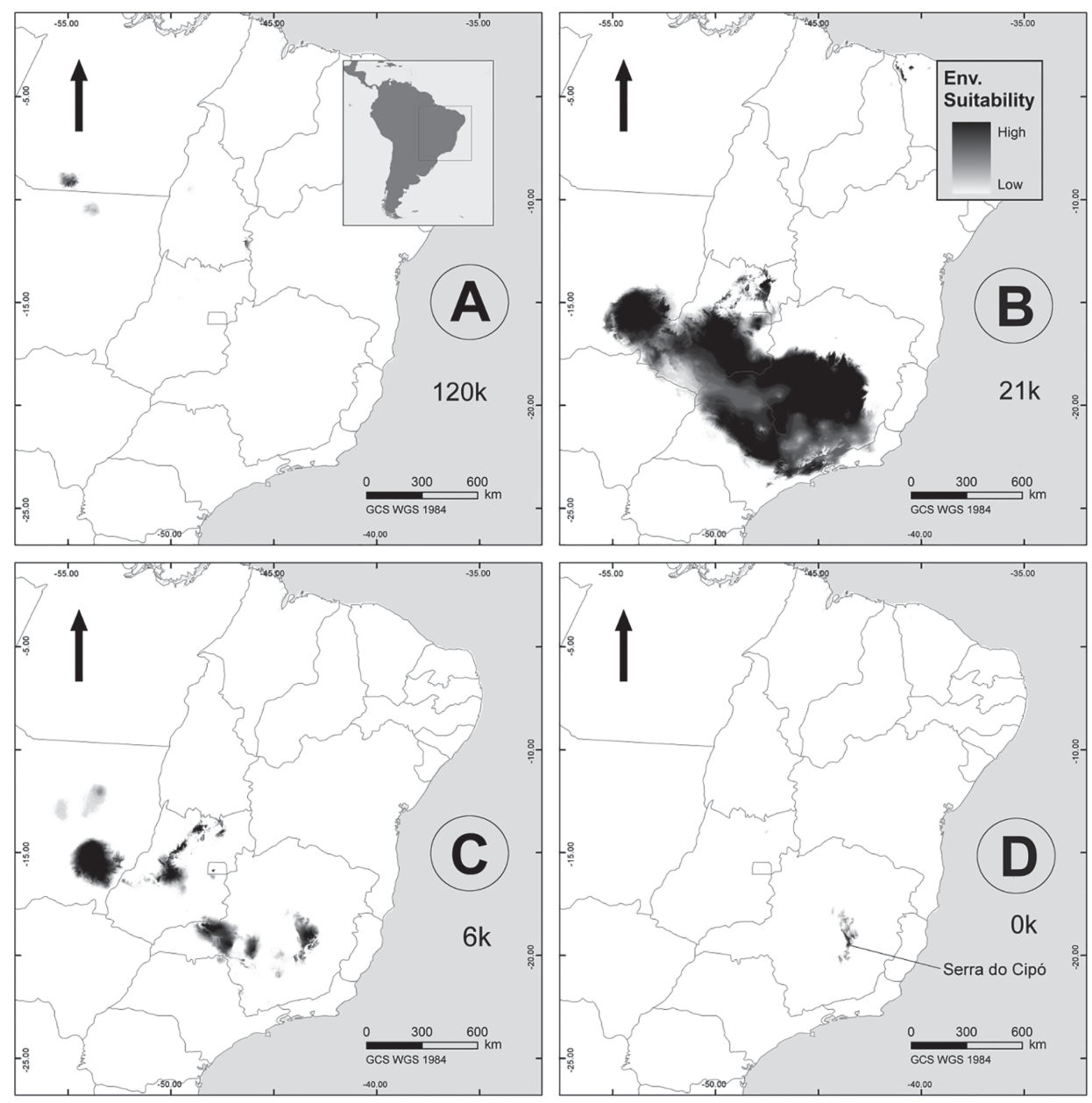

Figure 4. Environmental suitability for Coccoloba cereifera Schw. (Polygonaceae) in southeastern Brazil for the last interglacial maximum (A), last glacial maximum (B), mid-Holocene (C), and for a current scenario (D). 


\section{Discussion}

The presence of $C$. cereifera is strongly associated with sandy patches/grasslands (which show significantly low NDVI in dry season) formed among rocky outcrops (probably responsible for the high percentage of bare soil in predicted areas) by the deposition of locally formed sand (see Ribeiro \& Fernandes 1999; 2000). The importance of NDVI range and wet season NDVI were clearly highlighted in our study.

In southern, eastern and western sides of the core distribution area of $C$. cereifera (see Fig. 2), topographic features also seem responsible to constrain the species distribution. Specifically, the southern portion is limited by a physical barrier imposed by a deep canyon (the Travessão canyon). In Vellozia gigantea (Velloziaceae) this physical barrier limits gene flow leading to different population genetic structures on each side of this canyon (Lousada et al. 2011). To the west and east portions, high slopes are probably acting as barriers to the dispersion of C. cereifera, since the species may have some difficulty to disperse, in view of its clonal distribution and unknown pollinator system (Ribeiro \& Fernandes 2000; Silva et al. 2008). Though the species sets fruit during rainy season, little is known about the existence of dispersal for these fruits (Belo et al. 2013).

All areas predicted outside the occurrence core area (as we can see in model 2) should be understood as part of the fundamental niche of C. cereifera, which does not match the presence of the species (Pearson et al. 2007; Thorn et al. 2009). One small southern region, for instance, shows high environmental suitability, but the only record of $C$. cereifera there comes from the 1970's (Herbarium of The New York Botanical Garden, accessed through GBIF Data Portal, data. gbif.org, 2010-09-15). However, the region is now densely populated with a high degree of land disturbance, which might explain the current absence of the species.

Although we can observe that the species is distributed across early morning wet soils, the wet index was not important in the distribution model of the species. One explanation for the high humidity in the morning is the fog arising from clouds in surrounding CAP areas. The discussion of the effects of fog on plants is well developed. Scott (1890) already questioned its effects on plants. Fog may constitute a significant fraction of the total hydrologic input in an ecosystem during particular periods, such as the growing season, when plant demand for water is high (Breazeale et al. 1950; Dawson 1998). Fog or cloud water could help to diminish the stress effects in these extremely xeric areas by reducing plant transpiration or evaporation from the habitat and by improving plant water status by direct absorption through the foliage (e.g., Huntley et al. 1997; Dawson 1998; Teixido \& Valladares 2014). An interesting point is the fact that CAP areas seem responsible for shrinking the distribution of C. cereifera, as shown in Figure 3. In fact, some surrounding regions are constantly covered by low clouds (NPUB, GWF, personal observation). This phenomenon occurs frequently in basins, valleys and sinks of mountain regions and can have a substantial impact on much species phenology, diversity and distribution (Rodrigo 2000; Chung et al.2006; Daly et al. 2009), including C. cereifera (Fernandes et al. 2011). However, in the case of C. cereifera, the potential CAP area restricts the distribution of the species and may be related to the susceptibility of this species (and the majority of rupestrian grasslands species, e.g., Kolbek \& Alves 2008) to multiple frosts, more common in these valley areas (Clements et al. 2003). Potential cold air pooling areas are an important variable that shape many microrefugia areas along the Pleistocene climatic fluctuations (Dobrowsky 2011), as may have a strong influence on this species distribution.

Indeed, climate fluctuations that occurred in South America during the Pleistocene period are not yet fully known. Data for the Pleistocene and Holocene in mountain regions of Espinhaço are often conflicting. However, a consensus exists that at least the southern part of this mountain chain was cooler and drier during the last glacial maxima than in present time (Vuilleumier 1971; Ledru 1993; Stute et al. 1995; Behling 1998; 2002; Ab'Saber 2000; Behling \& Hooghiemstra 2001). In addition, the low atmospheric $\mathrm{CO}_{2}$ levels of this period probably enhanced plant water loss (Mayle et al. 2004), maximizing the dryness. This scenario would also have contributed to a decrease in CAP intensity in these areas, which in turn may have been important to the spread of C. cereifera and/or its congeners to broad areas as we can see in model 2 (Fig. 4). During this period the vegetation zones in tropical South America may have lowered their distribution to ca. $1 \mathrm{~km}$ (Rind \& Peteet 1985; Clapperton 1990; Stute et al. 1995); thus implying that the rupestrian grassland vegetation of the Espinhaço mountain chain may have been able to spread into areas much lower in elevation than those currently found (e.g., Vuilleumier 1971), such as those that today are covered by cerrado (savannah) vegetation. Temperatures in the highlands may have reached below $-5^{\circ} \mathrm{C}$ according to Behling \& Lichte (1997). Furthermore, it is hypohtesized that many thermophillous species (shrubs and trees) may have become locally extinct in these summits, which were covered solely by the cold adapted grassland vegetation, similar to the steppes (see Behling 2002).

Microrefugia are believed to be found in terrain positions that promote the consistent decoupling of the boundary layer from the free-atmosphere and can support once prevalent regional climates that have been lost due to climate shifts (Dobrowsky 2011). It seems that the actual distribution area of $C$. cereifera works as an interglacial microrefugium for the species, whose ancestral species may have had a much wider distribution due to a higher environmental suitability and also less environmental restrictions, e.g., CAP areas (Fig. 4). The germinative behaviour of Miconia 
corallina (Melastomataceae) in this small area, for example, provides support for local adaptation of the inhabiting species, as in this core area individuals present dormant seeds, while outside of it seeds are non-dormant (Silveira et al. 2011). Among-population variation in seed dormancy and germination is strongly related to climatic conditions. Several other relict species are also found only in the Coccoloba microrefugium, such as the shrub Chamaecrista semaphora (Fabaceae), and the treelet Collaea cipoensis (Fabaceae) (Madeira \& Fernandes 1999; Negreiros et al. 2008), among many others.

The existence of a microrefugium could have played a key role in the local processes that derived in the narrow distribution of $C$. cereifera. These are not necessarily present-day processes, and are probably partially due to reliction and extinction, following range contraction of formerly more widespread species as a result of climatic changes (e.g., Harley \& Simmons 1986). The presence of plants in microrefugia is likely to be a phenomenon more common than previously expected. Most endemism and species richness intrinsic to the rupestrian grasslands could have been shaped in this way, such as the case of Croton arlinae, a plant restricted in a small area smaller than $1 \mathrm{~km}^{2}$ at São José Mountains (Medeiros et al. 2002).

The adaptation of species in microrefugia has many implications on the rates of genetic divergence under climate change (Hewitt 2000; Stewart et al. 2004) and also great implications to distribution modelling. Dobrowsky et al. (2006) constructed distribution models for the mountain species Abies magnifica in Sierra Nevada, USA, using data with and without cold-air pooling effects (related to microrefugia). Under a $4^{\circ} \mathrm{C}$ warming scenario the results varied greatly. The first model, without cold-air pooling effects, predicts that there is no environmental suitability within the study region in this hypothetical warm future, whereas the second model identifies potential microrefugia in valley bottoms.

The great challenge for the projection of C. cereifera distribution in the future is the scarcity of climatic data. Critically important is the creation of physiographically informed climate data to the modelling of this and other restrict and endemic species of mountain regions (Clements et al. 2003; Lundquist et al.2008). The existence of a network of weather stations is essential for the development of more realistic modelling of present and future distribution of these species. Otherwise, mountains represent the most likely global regions where we may record the first footprints of climate change (IPCC 1996). In the tropics, these regions are inhabited by diverse flora and fauna, with high degree of endemism, and are where species struggle with the harsh environment and ever growing human induced disturbances (see Fernandes et al. 2014).

From a management point of view, the existence of a microrefugium in this area calls for changes in conservation tactics. Although the traits of the species suggest that it may be capable of surviving tem- porally in small isolated areas, even under climatic changes, the recent and recurrent introductions of non-native invasive species, grazing, tourism, and frequent fires represent strong threats to the existence of C. cereifera and other sympatric species (see Viana et al. 2005; Barbosa et al. 2010; Moreira et al. 2010; Fernandes et al. 2011; 2014; Carvalho et al. 2012). This scenario is more worrying due to the fact that the distribution area of $C$. cereifera is not within the strictly protected area of Parque Nacional da Serra do Cipó, albeit the species is found in an area of some protection status (APA Morro da Pedreira), Overall, these conditions make this microrefugium species and area worth of further detailed studies and conservation efforts.

\section{Acknowledgements}

We are grateful to Moreira R.G. and Cornelissen T.G. for their help in providing data for occurrence points and Loreto P.Y., Alberto L. Teixido and Hesketh M. for suggestions on the text. We thank the grants and logistic support of the Conselho Nacional de Pesquisa (CNPq: 140655/2008-5, 55 8250/20092, 474292/2010-0, 30 3352/2010-8, 151431/2014-0), CAPES (PGCI 02/2009, BEX 3236/10-2), Fundação de Amparo à Pesquisa do Estado de Minas Gerais, Natural Reserve Vellozia, and the Department of Earth Sciences of the University of Alberta for the work space. We also thank the MaxEnt discussion group for all appointments. This study was in partial fulfillment of the Ph.D. requirements of Barbosa N.P.U..

\section{References}

Ab'Saber AN. 2000. Spaces occupied by the expansion of dry climates in South America during the Quaternary ice ages. Revista do Instituto Geológico 21: 71-78.

Alves RJV, Kolbek J. 2010. Can campo rupestre vegetation be floristically delimited based on vascular plant genera? Plant Ecology 207: 67-79.

Alves RJV, Silva NG, Oliveira JA, Medeiros D. 2014. Circumscribing campo rupestre - megadiverse Brazilian rocky montane savanas. Brazilian Journal of Biology 74: 355-362.

Araújo MB, Peterson AT. 2012. Uses and misuses of bioclimatic envelope modelling. Ecology 93: 1527-1539.

Arroyo MTK, Dudley LE, Pliscoff P, et al. 2010. A possible correlation between the altitudinal and latitudinal ranges of species in the high elevation flora of the Andes. In: Spehn EM, Körner C. (eds.) Data Mining for Global Trends in Mountain Biodiversity. Boca Raton, CRC Press, Taylor and Francis. p. 39-47.

Barbosa NPU. 2012. Modelos de distribuição aplicados aos campos rupestres. PhD Thesis, Universidade Federal de Minas Gerais, Brazil.

Barbosa NPU, Fernandes GW, Carneiro MAA, Júnior LAC. 2010. Distribution of non-native invasive species and soil properties in proximity to paved roads and unpaved roads in a quartzitic mountainous grassland of south-eastern Brazil (rupestrian fields). Biological Invasions 12: 3745-3755.

Behling H. 1998. Late Quaternary vegetational and climatic changes in Brazil. Review of Paleobotany and Palynology 99: 143-156.

Behling H. 2002. South and southeast brazilian grasslands during late quaternary times: a synthesis. Paleogeography, Pleoclimatology, Paleoecology 177: 19-27. 
Behling H, Hooghiemstra H. 2001. Neotropical savanna environments in space and time: Late Quaternary interhemispheric comparisons. In: Markgraf V. (ed.) Interhemispheric climate linkages. Academic press. p. 307-323.

Behling H, Lichte M. 1997. Evidence of dry and cold climatic conditions at glacial times in tropical southeastern Brazil. Quaternary Research 48: 348-358.

Belo RM, Negreiros D, Fernandes GW, Silveira FAO, Ranieri BD, Morellato PC. 2013. Fenologia reprodutiva e vegetativa de arbustos endêmicos de campo rupestre na Serra do Cipó, Sudeste do Brasil. Rodriguésia 64: 817-828.

Beven KJ, Kirkby MJ. 1978. A physically based, variable contributing area model of basin hydrology. Hydrological Sciences - Bulletin - des Sciences Hydrologiques 24: 43-69.

Breazeale EL, McGeorge WT, Breazeale JF. 1950. Moisture absorption by plants from an atmosphere of high humidity. Plant Physiology 25: 413-419.

Brown DG. 1994. Comparison of vegetation-topography relationships at the alpine treeline ecotone. Physical Geography 15: 125-145.

Carnaval AC, Moritz C. 2008. Historical climate modelling predicts patterns of current biodiversity in the Brazilian Atlantic forest. Journal of Biogeography 35: 1187-1201.

Carvalho F, Souza FA, Carrenho R, Moreira FMS, Jesus EC, Fernandes GW. 2012. The mosaic of habitats in the high-altitude Brazilian rupestrian fields is a hotspot for arbuscular mycorrhizal fungi. Applied Soil Ecology 52: 9-19.

Chung U, Seo HH, Hwang KH, et al. 2006. Minimum temperature mapping over complex terrain by estimating cold air accumulation potential. Agricultural and Forest Meteorology 137: 15-24.

Clapperton CM. 1990. Quaternary glaciations in the southern hemisphere: An overview. Quaternary Science Reviews 9: 299-304.

Clements CB, Whiteman CD, Horel JD. 2003. Cold-Air-Pool Structure and Evolution in a Mountain Basin: Peter Sinks, Utah. Journal of Applied Metereology 42: 752-768.

Daly C, Conklin DR, Unsworth MH. 2009. Local atmospheric decoupling in complex topography alters climate change impacts. International Journal of Climatology 30: 1857-1864.

Dawson TE. 1998. Fog in the California redwood forest: ecosystem inputs and use by plants. Oecologia 117: 476-485.

DKRZ. 1992. The ECHAM3 atmospheric general circulation model. DKRZ Technical Report No. 6. Deutsches Klimarechenzentrum: Hamburg.

Dobrowski SZ. 2011. A climatic basis for microrefugia: the influence of terrain on climate. Global Change Biology 17: 1022-1035.

Dobrowski SZ, Greenberg JA, Ramirez CM, Ustin SL. 2006. Improving image derived vegetation maps with regression based distribution modeling. Ecological Modelling 192: 126-142.

Echternacht L, Trovó M, Oliveira CT, Pirani JR. 2011. Areas of endemism in the Espinhaço Range in Minas Gerais, Brazil. Flora 206: 782-791.

Elith J, Graham CH, Anderson RP, et al. 2006. Novel methods improve prediction of species' distributions from occurrence data. Ecography 29: 129-51.

Elith J, Phillips SJ, Hastie T, Dudik M, Chee YE, Yates CJ. 2011. A statistical explanation of MaxEnt for ecologists. Diversity and Distributions 17: 43-57.

Fernandes GW, Price PW. 1991. Comparisons of tropical and temperate galling species richness: the roles of environmental harshness and plant nutrient status. In: Price PW, Lewinsohn TM, Fernandes GW, Benson WW. (eds.) Plant-animal interactions. New York, Wiley \& Sons. p. 91-115.

Fernandes GW, Oki Y, Sanchez-Azofeifa A, Faccion G, Amaro-Arruda H.C. 2011. Hail impact on leaves and endophytes of the endemic threatened Coccoloba cereifera (Polygonaceae). Plant Ecology 10: 1687-1697.

Fernandes GW, Barbosa NPU, Negreiros D, Paglia AP. 2014. Challenges for the conservation of vanishing megadiverse rupestrian grasslands. Natureza \& Conservação - Brazilian Journal of Nature Conservation 12: $162-165$.

Fielding AH, Bell JF. 1997. A review of methods for the assessment of prediction errors in conservation presence/absence models. Environmental Conservation 24: 38-49.
Geiger RJ. 1965. The climate near the ground. Cambridge, Harvard University Press.

Giulietti AM, Menezes NA, Pirani JR, Meguro M, Vanderley MGL. 1987. Flora da Serra do Cipó: caracterização e lista de espécies. Boletim Botânico 9: 1-151.

González-Astorga J, Vovides AP, Cruz-Angon A, Octavio-Aguilar P, Iglesias C. 2005. Allozyme Variation in the Three Extant Populations of the Narrowly Endemic Cycad Dioon angustifolium Miq. (Zamiaceae) from North-eastern Mexico. Annals of Botany 95: 999-1007.

Hampe A, Jump AS. 2011. Climate Relicts: Past, Present, Future. Annual Review of Ecology, Evolution, and Systematics 42: 313-333.

Hansen M, DeFries R, Townshend JRG, Carroll M, Dimiceli C, Sohlberg RA. 2003. "Global Percent Tree Cover at a Spatial Resolution of 500 Meters: First Results of the MODIS Vegetation Continuous Fields Algorithm". Earth Interact 7: 1-15.

Harley RM, Simmons NA. 1986. Florula of Mucuge. London, Kew Royal Botanical Gardens.

Hernandez PA, Graham CH, Máster LL, Albert DL. 2006. The effect of sample size and species characteristics on performance of different species distribution modeling methods. Ecography 29: 773-85.

Hewitt G. 2000. The genetic legacy of the quaternary ice ages. Nature 405: 907-913.

Hijmans RJ, Cameron SE, Parra JL, Jones PG, Jarvis A. 2005. Very high resolution interpolated climate surfaces for global land areas. International Journal of Climatology 25: 1965-1978.

Holderegger R, Thiel-Egenter C. 2009. A discussion of different types of glacial refugia used in mountain biogeography and phylogeography. Journal of Biogeography 36: 476-480.

Huntley LB, Doley D, Yayes DJ, Boonsaner A. 1997. Water balance of an Australian subtropical rainforest at altitude: the ecological and physiological significance of intercepted cloud and fog. Australian Journal of Botany 45: 311-329.

IPCC - Intergovernmental Panel on Climate Change. 1996. Climate change 1995: the science of climate change. Contribution of working group I to the second assessment report of the IPCC. New York, Cambridge University Press.

Janzen DH. 1967. Why mountain passes are higher in the tropics. The American Naturalist 101: 233-249.

Keppel G, Niel KPV, Wardell-Johnson GW, et al. 2011. Refugia: identifying and understanding safe havens for biodiversity under climate change. Global Ecology and Biogeography 21: 393-404.

Kolbek J, Alves RJV. 2008. Impacts of cattle, fire and wind in Rocky Savannas, Southeastern Brazil. Acta Universitatis Carolinae Biologica 22: $111-130$

Kumar S, Stohlgren TJ. 2009. MaxEnt modeling for predicting suitable habitat for threatened and endangered tree Canacomyrica monticola in New Caledonia. Journal of Ecology and The Natural Environment 1: 94-8.

Ledru MP. 1993. Late quaternary environmental and climatic changes in central Brazil. Quaternary Research 39: 90-98.

Liu C, Berry PM, Dawson TP, Pearson RG. 2005. Selecting thresholds of occurrence in the prediction of species distributions. Ecography 28: $385-393$

Lousada JM, Borba EL, Ribeiro KT, Ribeiro LC, Lovato MB. 2011. Genetic structure and variability of the endemic and vulnerable Vellozia gigantea (Velloziaceae) associated with the landscape in the Espinhaço Range, in southeastern Brazil: implications for conservation. Genetica 139: 431-440.

Lundquist JD, Pepin N, Rochford C. 2008. Automated algorithm for mapping regions of cold-air pooling in complex terrain. Journal of Geophysical Research 113: D22107.

Lüttge U, Duarte HM, Scarano FR, et al. 2007. Physiological ecology of photosynthesis of five sympatric species of Velloziaceae in the rupestrian fields of Serra do Cipó, Minas Gerais, Brazil. Flora 202: 637-646.

Madeira JA, Fernandes GW. 1999. Reproductive Phenology of Sympatric Taxa of Chamaecrista (Leguminosae) in Serra do Cipó, Brazil. Journal of Tropical Ecology 15: 463-479. 
Manel S, Williams HC, Ormerod SJ. 2001. Evaluating presence-absence models in ecology: the need to account for prevalence. Journal of Applied Ecology 38: 921-931.

Marques AR, Fernandes GW, Reis IA, Assunção RM. 2002. Distribution of adult male and female Baccharis concinna (Asteraceae) in the rupestrian fields of Serra do Cipó. Plant Biology 4: 94-103.

Martinelli G. 2007. Mountain biodiversity in Brazil. Revista Brasileira de Botânica 30: 587-597.

Martínez-Freiría F, Velo-Antón G, Brito JC. 2014. Trapped by climate: interglacial refuge and recent population expansion in the endemic Iberian adder Vipera seoanei. Diversity and Distributions. Early view. doi: 10.1111/ddi.12265.

Mayle FE, Beerling DJ, Gosling WD, Bush MB. 2004. Responses of Amazonian ecosystems to climatic and atmospheric carbon dioxide changes since the last glacial maximum. Philosophical Transactions of the Royal Society of London B 359: 499-514.

McLachlan JS, Clark JS, Manos PS. 2005. Molecular indicators of tree migration capacity under rapid climate change. Ecology 86: 2088-2098.

Medeiros D, Valle LS, Alves RJV. 2002. Espécie nova de Croton L. (Euphorbiaceae) do Estado de Minas Gerais, Brasil. Bradea 8: 299-302.

Medina BMO, Fernandes GW. 2007. The potential of natural regeneration of rocky outcrop vegetation on rupestrian fields soils in "Serra do Cipó", Brazil. Revista Brasileira de Botânica 30: 665-678.

Miller GH, Lehman SJ, Refsnider KA, Southon JR, Zhong Y. 2013. Unprecedented recent summer warmth in Arctic Canada. Geophysical Research Letters 40: 5745-5751.

Mittermeier RA, Robles Gil P, Mittermeier CG. 1997. Megadiversity: Earth’s Biologically Wealthiest Nations. Monterrey, CEMEX.

Moreira RG, McCauley RA, Cortés-Palomec AC, Lovato MV, Fernandes GW, Oyama K. 2008. Isolation and characterization of microsatellite loci in Coccoloba cereifera (Polygonaceae), an endangered species endemic to the Serra do Cipó, Brazil. Molecular Ecology Resources 8: 854-856

Moreira RG, McCauley RA, Cortés-Palomec AC, Fernandes GW, Oyama, K. 2010. Spatial genetic structure of Coccoloba cereifera (Polygonaceae), a critically endangered micro endemic species of Brazilian rupestrian fields. Conservation Genetics 11: 1247-1255.

Morrone JJ. 1994. On the Identification of Areas of Endemism. Systematic Biology 43: 438-444.

Morrone JJ. 2001. Homology, biogeography and areas of endemism. Diversity and Distributions 7: 297-300.

Mosblech NAS, Bush MB, Woesik R. 2011. On metapopulations and microrefugia: palaeoecological insights. Journal of Biogeography 38: 419-429.

Müller P. 1973. The dispersal centres of terrestrial vertebrates in the Neotropical realm: A study in the evolution of the Neotropical biota and its native landscapes. The Hague, Junk.

Negreiros D, Fernandes GW, Berbara RLL, Rodarte LHO, Barbosa NPU. 2012. Caracterização físico-química de solos quartzíticos degradados e áreas adjacentes de campo rupestre na Serra do Cipó, MG, Brasil. Neotropical Biology and Conservation 6: 156-161.

Negreiros D, Moraes MLB, Fernandes GW. 2008. Caracterização da fertilidade dos solos de quarto leguminosas de campos rupestres, Serra do Cipó, MG, Brasil. Revista de la Ciencia del Suelo y Nutrición Vegetal 8: 30-39.

Otto-Bliesner BL, Marshall SJ, Overpeck JT, Miller GH, Hu A. 2006. Simulating Arctic Climate Warmth and Icefield Retreat in the Last Interglaciation. Science 311: 1751-1753.

Pearson RG. 2006. Climate change and the migration capacity of the species. Trends in Ecology and Evolution 21: 111-113.

Pearson RG, Dawson TP. 2003. Predicting the impacts of climate change on the distribution of species: are bioclimate envelope models useful? Global Ecology \& Biogeography 12: 361-371.

Pearson RG, Raxworthy CJ, Nakamura M, Peterson AT. 2007. Predicting species distributions from small numbers of occurrence records: a test case using cryptic geckos in Madagascar. Journal of Biogeography 34: 102-117.
Phillips SJ, Anderson RP, Schapire RE. 2006. Maximum entropy modelling of species geographic distributions. Ecological Modelling 190: 231-59.

Previšić A, Walton C, Kučinić M, Mitrikeski PT, Kerovec M. 2009. Pleistocene divergence of Dinaric Drusus endemics (Trichoptera, Limnephilidae) in multiple microrefugia within the Balkan Peninsula. Molecular Ecology 18: 634-647.

Rapini A, Ribeiro PL, Lambert S, Pirani JR. 2008. A flora dos campos rupestres da Cadeia do Espinhaço. Megadiversidade 4: 15-23.

Raxworthy C, Martinez-Meyer E, Horning N, et al. 2003. Predicting distributions of known and unknown reptile species in Madagascar. Nature 426: 837-841.

Ribeiro KT, Fernandes GW. 1999. Geographic distribution of Coccoloba cereifera Schw. (Polygonaceae), a narrow endemic plant from Serra do Cipó, Brazil. BIOS 7: 7-12.

Ribeiro KT, Fernandes GW. 2000. Patterns of abundance of a narrow endemic species in a tropical and infertile montane habitat. Plant Ecology 147: 205-218.

Richter M, Diertl K, Emck P, Peters T, Beck E. 2009. Reasons for an outstanding plant diversity in the tropical Andes of Southern Ecuador. Landscape Online 12: 1-35.

Rind D, Peteet D. 1985. Terrestrial conditions at the Last Glacial Maximum and CLIMAP sea-surface temperature estimates: Are they consistent? Quaternary Research 24: 1-22.

Rizzini CT. 1979. Tratado de fitogeografia do Brasil. 2nd. ed. São Paulo, Hucitec/ EDUSP.

Rodrigo J. 2000. Spring frosts in deciduous fruit trees - morphological damage and flower hardiness. Scientia Horticulturae 85: 155-173.

Rull V. 2009. Microrefugia. Journal of Biogeography 36: 481-484.

Rull V, Schubert C, Aravena R. 1988. Palynological studies in the Venezuelan Guayana Shield: preliminary results. Current Research in the Pleistocene 5: 54-56.

Safford HD. 1999. Brazilian Páramos I. An introduction to the physical environment and vegetation of the campos de altitude. Journal of Biogeography 26: 693-712.

Scherrer D, Körner C. 2010. Infra-red thermometry of alpine landscapes challenges climatic warming projections. Global Change Biology 16: 2602-2613.

Schrag AM, Bunn AG, Graumlich LJ. 2008. Influence of bioclimatic variables on treeline conifer distribution in the Greater Yellowstone Ecosystem: implications for species of conservation concern. Journal of Biogeography 35: 698-710.

Scott DH. 1890. The effect of fog on plants. Nature 43: 129.

Silva CA, Oliva MA, Vieira MF, Fernandes GW. 2008. Trioecy in Coccoloba cereifera Schwacke (Polygonaceae), a Narrow Endemic and Threatened Tropical Species. Brazilian Archives of Biology and Technology 51: 1003-1010.

Silveira FAO, Ribeiro RC, Oliveira DMT, Fernandes GW, Lemos-Filho JP. 2011. Evolution of physiological dormancy multiple times in Melastomataceae from Neotropical montane vegetation. Seed Science Research 22: 37-44.

Spehn EM, Rudmann-Maurer K, Körner C, Maselli D. 2010. Mountain Biodiversity and Global Change. GMBA-DIVERSITAS, Basel.

Stewart IT, Cayan D, Dettinger M.D. 2004. Changes toward earlier streamflow timing across western North America. Journal of Climate 18: 1136-1155.

Stute M, Forster M, Frischkorn H, et al. 1995. Cooling of Tropical Brazil $\left(5^{\circ} \mathrm{C}\right)$ During the Last Glacial Maximum. Science 269: 379-383.

Swets JA. 1988. Measuring the accuracy of diagnostic systems. Science 240: 1285-1293.

Tang Z, Fang J, Chi X, et al. 2012. Patterns of plant beta-diversity along elevational and latitudinal gradients in mountain forests of China. Ecography 35: 1-9.

Teixido AL, Valladares F. 2014. Disproportionate carbon and water use of large flowers in hot Mediterranean ecosystems. Perspective in Plant Ecology, Evolution and Systematics 16: 83-92.

Thorn JS, Nijman V, Smith D, Nekaris KAI. 2009. Ecological niche modelling as a technique for assessing threats and setting conservation priorities for Asian slow lorises (Primates: Nycticebus). Diversity and Distributions 15: 289-298. 
Vega R, Fløjgaard C, Lira-Noriega A, Nakazawa Y, Svenning JC, Searle J. B. 2010. Northern glacial refugia for the pygmy shrew Sorex minutus in Europe revealed by phylogeographic analyses and species distribution modelling. Ecography 33: 260-271.

Viana LR, Fernandes GW, Silva CA. 2005. 'Ecological road' threatens endemic Brazilian plant with extinction. Plant Talk 41: 15.

Vuilleumier BS. 1971. Pleistocene changes in the fauna and flora of South America. Science 173: 771-780.
Waltari E, Hijmans RJ, Peterson AT, Nyari A S, Perkins SL, Guralnick RP. 2007. Locating Pleistocene refugia: comparing phylogeographic and ecological niche model predictions. PLoS ONE 2:e563.

Werneck FP, Costa GC, Colli GR, Prado DE, Sites JW. 2010. Revisiting the historical distribution of seasonally dry tropical forests: new insights based on paleodistribution modelling and palynological evidence. Global Ecology and Biogeography 20: 272-288. 